\title{
Introduction to the Sociology of Wine-The Sociological Decanter: Pouring Sociology into Wine, and Vice Versa
}

\author{
David Inglis ${ }^{1 *}$, Anna-Mari Almila ${ }^{1}$
}

\author{
${ }^{1}$ University of Helsinki, FINLAND
}

\section{*Corresponding Author: david.inglis@helsinki.fi}

Citation: Inglis, D. and Almila, A.-M. (2021). Introduction to the Sociology of Wine-The Sociological Decanter: Pouring Sociology into Wine, and Vice Versa, Journal of Cultural Analysis and Social Change, 6(2), 08. https://doi.org/10.20897/jcasc/11446

Published: January 11, 2022

\begin{abstract}
Wine from grapes is both ancient and highly modern, increasingly widespread across vast swathes of the planet, and made, marketed and distributed by a huge industry that directly and indirectly employs millions of people and generates huge profits, at least for some. Yet despite wine's social and cultural importance, sociology and sociologists have remained remarkably quiet about wine, unlike those in other academic disciplines. There is today no such thing as a scholarly field called the sociology of wine. This introductory paper to the special issue on wine and sociology considers this state of affairs, and what might be done about overcoming the relative silence of sociology on wine matters. It offers an extensive literature review covering what international sociological work there is on the wine/sociology interface, considering this relatively modest body of literature in relation to the more voluminous amounts of wine-related analysis offered by anthropologists, geographers, economists, and others. These scholarly domains are represented in the paper by reference to classic works and indicative readings. The paper poses a series of questions as to what a sociological field of wine analysis could look like, and what it would take to build such a thing. It also illustrates how the papers published in the special issue contribute to posing and answering some of these questions.
\end{abstract}

Keywords: wine, economics, sociology, anthropology, geography

\begin{abstract}
All stultifying drunkenness, such as comes from opium or brandy, that is, drunkenness which does not encourage sociability or the exchange of thought, has something shameful about it. Wine and beer provide intoxication for social purposes; wine has simply a stimulating effect, while beer is more nourishing and satisfying like food. There is, however, a characteristic difference. The beer-drinking bout is associated with taciturn fantasies, and frequently with impolite behaviour (Kant, 1798 [1996]: 59).
\end{abstract}

Thus spoke one of the West's great philosophers, espousing the highly conventional view that, while wine makes you witty, because it is a civilized and civilizing beverage, beer makes you moody or ready for a fight. Since then, the discipline of philosophy has engaged with the nature of wine and wine drinking sporadically, sometimes bringing in more 'social' concerns, but often treating wine matters as if they existed in a sociological vacuum (Allhoff, 2007; Peters, 2009; Smith, 2007). That raises the question of where is sociology when it comes to considerations of wine, and how people make it, sell it, drink it, and talk about it?

As the wine spills out of the bottle, so does the ink. It is impossible to enumerate how many words have been written about wine since humans started making an alcoholic drink from certain kinds of grapes about 8,000 years ago. Wine seems to be particularly alluring for wordsmiths: poets have praised it, religious authors have both eulogised and condemned it, aficionados wax lyrically about it, technical specialists produce reams of text about it, 
industry professionals earn their livings discursively presenting it, popular writers present overviews of wine to broadening publics (e.g. Estreicher, 2006; Millon, 2013; Phillips, 2018), commentators present sometimes polemical texts ranged against the contemporary ills of the wine world as they see it (Nossiter, 2009), and today different sorts of academics engage with it through the lenses of disciplinary specialisations. Wine and words have become inextricably entwined, with the latter not only describing the former but also actively shaping it in multiple manners.

Yet sociologists have remained remarkably quiet about wine, despite their loquaciousness otherwise, and their capacity to analyse just about everything else imaginable which exists on the planet. Few sociologists, relative to the total number of them, have systematically engaged with wine, either in the past of the discipline or today. This has been so both in the countries which have historically had little or no wine-making traditions, and, perhaps more surprisingly, in countries like France, Italy, and Spain, which have long-standing wine industries.

It is not going too far to claim that there is today no such thing as a (sub-)field called the sociology of wine, let alone a systematically and coherently organised field that could be termed the social science of wine more broadly. This is particularly strange given the importance and significance of wine and wine-related phenomena across the world at the present time.

Sociology's historical and current neglect of wine matters is especially odd given the social, socio-cultural, socioeconomic, and socio-political forms of significance wine has had in the past and continues to have today. Wine's various significances are in fact today not diminishing but instead growing and spreading to ever more parts of the world. As wine making and drinking have become more geographically extensive, the various roles wine plays in the lives of different sorts of people have expanded and complexified too. More persons of more diverse types nowadays drink wine than was ever the case before. Wine is made in more diverse places than ever before too. The apparently simple word 'wine' actually refers to multiple constellations of heterogeneous, complexly interlinked, phenomena, all of which have significant social and societal presences. Therefore, wine should certainly be a matter of major interest for sociology in general, and for sociologists of many different types.

Wine today can be understood as being organised in terms of industries (which make and sell wine), worlds (which socially organise wine drinking) and cultures (which construct the appreciation and understanding of wine by different groups of drinkers) (Inglis and Almila, 2019). Sociology has by and large ceded the study of wine industries, worlds, and cultures to other disciplines. Yet all of these encompass tens of millions of Dollars of economic activity annually. They involve tens of thousands of people directly, and many more indirectly, in the production, distribution and sale of wine. Many more millions of people drink wine, regularly or occasionally. Wine is produced on a massive scale, with billions of litres produced annually. Wine production contributes hugely both to the economies of producer countries and to the tax revenues of importer countries (Veseth, 2012). Wine is both highly globalized in multiple ways, and also a means by which globalization - of taste, lifestyle, profession, and so on - is developed, promoted, spread, thematized, and sometimes resisted, by many different sorts of people (Inglis, 2019b).

Thus, even in the simplest terms of economic significance and the large numbers of people involved in winerelated activities, wine is an important element in and of large parts of the world today. That significance is growing all the time, sometimes very rapidly indeed. From Denmark to Thailand, new wine producing areas are coming into existence and prominence (Anderson and Pinilla, 2019). At the same time, new groups of wine drinkers are appearing, not just in the more spectacular cases of China and east Asia (see Ho, 2021a), but also among lower social groups in more established wine drinking contexts, as is the case in north-western Europe. Wine drinking is becoming ever more an accepted part of middle-class lifestyles around the world, or at least a component of aspirations towards them (Colman, 2008).

Today's wine industries, worlds and cultures are globalized in complex and intricate ways. Ownership of vineyards and wineries varies from massive multinationals to tiny independent producers. While wine is booming in certain ways and in specific locations, it is in deep crisis in others (Anderson, 2004). The complexly globalized nature of wine both reflects, refracts, and in some ways contributes to, much broader social, cultural, economic and political processes, including the changing politics of nationalism, post- and re-nationalization, neocolonization, neo-liberalization of markets and industries (and de-liberalizing trends, such as trade wars), Europeanization (and its opposites), post-industrialization, social and cultural reconfiguration and fragmentation, cosmopolitization (and its antagonists), and (late- or post-) modernization (Inglis and Almila, 2019). Wine is created in and through such processes, as well as being an important index of how they are working and in which directions they are moving.

Wine is profoundly caught up in issues to do with labour struggles and exploitation (Guy, 2019), and the politicization and publicization of these for diverse audiences of consumers (Herman, 2018, 2019). Wine is also deeply tied to phenomena of climate crisis, ranging from the degradation of environments caused by unsustainable vineyard practices, through to older wine-growing areas being undermined by climate change, at the same time as new locales are made possible for wine making by rising temperature levels (Almaraz, 2015; Ashenfelter and 
Storchmann, 2012; Nicholas, 2015; Pincus, 2003). Wine is thoroughly bound up with contemporary 'politics of nature', with increasing numbers of producers and distributors keen to promote their 'green' credentials to ever more environmentally concerned groups of consumers (Dans et al., 2019).

All the above points to the great, and increasing, social, societal, cultural, political and economic significance of wine in and across the world today. So, it is particularly remarkable that sociology, which otherwise is meant to be, and is, engaged with the sorts of processes indicated above, barely deals with wine, either now or in the recent past. The absence of much sociological analysis of wine is a notable feature of contemporary sociology, and a peculiar and perhaps rather troubling one too.

Nonetheless, instances of sociological thinking being applied to various aspects of wine, both in terms of production, distribution, and consumption, do exist. These are in the English, French, German, Spanish, and Italian languages (e.g., Chauvin, 2010; Corbeau, 2004; Diaz-Bone, 2005; Fischler, 1999; Germov, 2017; Herzog, 2020; Inglis and Almila, 2019; Navarini, 2015; Pape, 2012; Pinkert, 2017).

It is noteworthy that studies and ways of thinking emanating from particular countries tend to reflect and refract both the wider sociological field in a country, as well as that country's typical wine production and distribution systems and consumption culture. Thus, sociological studies of wine undertaken in France, and produced at least in part for a French audience, will most likely express certain theoretical and methodological tendencies to be found in wider French sociological circles, while at the same time tending to take production, distribution, and consumption phenomena occurring in France as their main object of study. This makes them rather different, in both epistemological and empirical terms, from, for example, comparable sociological studies carried out in Germany. While trans-national and cosmopolitan wine phenomena may be studied, they will probably be done so through quite nationally specific forms of sociology, and in terms of field-sites and trends that exist within the nation-state in question. That state of affairs raises the interesting question of what a more explicitly and systematically cosmopolitan sociology of wine could look like in the future.

Some sub-fields of sociology do sometimes deal with certain wine-related phenomena, usually as exemplars of more general issues of interest to specialists. Thus, economic sociology - probably the specialism that has had most to say about wine - deals with phenomena such as value judgments and price formation in markets, as well as auction-house dynamics (Beckert et al., 2017; Carter, 2019; Chiffoleau and Laporte, 2006; Karpik, 2010; OdyBrasier and Fernandez-Mateo, 2017; Zhao, 2005, 2008).

Cultural sociology - which in these matters often overlaps with economic sociology - has dealt with issues of collective classification of wine and wine regions (Allen and Germov, 2011; Fitzmaurice, 2017; Fourcade, 2012), as well as the development of the institution of wine criticism (Rössel et al., 2018), changing configurations of social class and other factors among wine connoisseurs (Howland, 2013; Rössel and Pape, 2014), and the aesthetics of wine labelling (Woodward and Ellison, 2012). There are occasional works in historical sociology which deal with wine matters, such as Rihouet's (2013) analysis of changing wine glass design in relation to Norbert Elias's conception of the European civilizing process.

Meanwhile, qualitative empirical sociological studies, of various theoretical persuasions, has deal with questions of wine tasting and appreciation (de Benedettis, 2019; Hennion, 2007; Teil and Hennion, 2004). These overlap with, and could in future take further inspiration from, interdisciplinary qualitative studies of similar matters, both of drinking and appreciating wine (Brighenti, 2018; Ducker, 2011; Hampton, 2012; Latkiewicz, 2003; Michalski, 2013; Silverstein, 2016; Skinner, 2016; Sternsdorff, 2014; Vannini et al., 2010), and of making it (Berkowitz, 2014; Dans et al., 2019; Lukacs, 2002; Stephens and Neil, 2010).

Sociology of consumption, as well as the wider consumer studies field which it contributes to, contains some consideration of wine matters, but perhaps not as much as one might expect, given the increasing presence of wine over the last few decades in the lives of those consumers these studies otherwise touch upon (useful studies that are nor explicitly sociological in nature but which have clear sociological relevance include Groves et al. (2000), Mora and Moscarola (2010), and Zhang (2018)). The work of Smith Maguire, which traverses sociology, marketing, organization studies, media studies, and other fields, has pursued a range of interesting approaches to wine over the last decade and more (e.g. Smith Maguire, 2013, 2018a, 2018b, 2018c, 2019a, 2019b; Smith Maguire and Charters, 2021; Smith Maguire and Lim, 2015), and she pursues a distinctive line of thought about sociology's relations to wine in this volume.

Issues of gender and gendered inequalities in wine have been dealt with to a certain extent in some disciplinary contexts (Atkin et al., 2007; Barber et al., 2006; Bryant and Garnham, 2014; Kennedy, 2017; Martin, 2001; Matasar, 2006; Mayor, 1994; Nicolson, 1990; Parasecoli, 2010; Russell, 2003), and are beginning to be attended to from sociological perspectives (Almila, 2019; Inglis and Almila, 2022). One such approach is presented in this volume by Almila (2021).

The racial and ethnic aspects of wine remain radically understudied (exceptions are Crenn, 2015 and Peace, 2006). This is despite the fact that major intellectuals like Jean-Paul Sartre (2001) and Roland Barthes (2013 [1957]), 
and, perhaps more obliquely, the eminent sociologist Pierre Bourdieu (Haddour, 2009) had already commented, in the time of the late French imperial period, about the heavy price paid by native Algerians, when the French colonial regime restructured the agriculture of the country to create a huge amount of terrain under vine that would service the demand for cheap, basic wine in metropolitan France. The relative lack of scholarly attention to matters of ethnic biases and inequalities in wine making and drinking will likely change as the Black Lives Matter movement has increased calls for the decolonization of wine, both in terms of professional practices and the languages they operate with, and also in terms of consumption dynamics too (Inglis and Ho, 2022).

How gender, ethnicity and class intersect with age and generations is also another area that marketing literature points towards (Atkin and Thach, 2012), but which the other social sciences have barely touched, as yet. An approach to wine matters informed by the sociology of generations in general, and the sociology of trans-national and putatively 'global' generations in particular (Thorpe and Inglis, 2019), would resonate well with issues to do with mass market wine drinking as part of the quotidian lifestyles of generational formations within the so-called 'global middle class' (Smith Maguire, 2019a).

So, today there exist some sociological inroads into wine matters, but such analyses have appeared, and continue to appear, sporadically, and not in ways suggestive of the existence of a systematic body of accumulating knowledge or of a well-organised international field of study. Why this relative neglect of wine by sociologists has existed and continues to exist is something of a puzzle. Cognate social sciences, especially geography and anthropology, and the discipline of history - which spans the social sciences and humanities - have seemingly had no such inhibitions about engaging with wine. It is they, rather than sociology, which majorly contribute to the emerging interdisciplinary field of 'wine studies' (Black and Ulin, 2013; Charters, 2006; Dutton and Howland, 2019; Harvey et al., 2014; Howland, 2022; Inglis and Almila, 2019; Lachaud-Martin et al., 2021; Morgan and Tresidder, 2016; Patterson and Buechsenstein, 2018). The field is both well represented in, and brought into more concrete and self-conscious existence by, a recent major handbook which offers a synthesis of the field at the present time (Charters et al., 2022).

The nearest discipline to sociology which gives wine issues some sustained consideration is anthropology. To a certain extent, a self-conscious field called the 'anthropology of wine' does exist, although it is a relatively small specialism within the wider discipline. The edited book by Black and Ulin (2013) brings together many of the major contributors to this sub-field. Two of the most prominent practitioners are Demossier (1997, 2005, 2010, 2011, 2013, 2018) and Ulin (1987, 1995, 2002, 2004, 2013), the former's fieldwork concerning Burgundy, and the latter's dealing with the south-west of France. Ulin's writing brings in neo-Marxist conceptions to understand power inequalities in the wine making areas he is concerned with. Other anthropological or semi-anthropological analyses of wine growing areas and specific industries include Trubek (2008) and Domingos (2016).

Along with sociology, anthropology is one of the contributing disciplines to the interdisciplinary constellation of Science and Technology Studies (STS), and those disciplines in return take up ideas created within STS. Notable STS writing on wine has emerged over the last decade or so, involving analysis of such phenomena as the means by which far-flung producers and consumers become connected with each other (some of it is summarised in Itçaina, Roger and Smith, 2016). It includes the work of the historian of science Shapin (2012, 2016) on formations of wine tasting, the sociologist Hennion's (2007; also Teil and Hennion, 2004) Actor-Network Theory-inspired and pragmatist analysis of tasting practices (intended as a sharp critique of Bourdieu's (1984) understanding of wine as primarily a marker of social status), and Genevieve Teil's (2012) analysis - which is also a contribution to economic sociology - of the collective work involved in creating terroir (also Teil et al., 2011).

The strongly relational epistemology of STS studies - concerned to understand how human-to-human and human-to-non-human relations operate - are clearly close to sociological considerations, and stand in contrast to the sometimes more human individual-oriented approaches to the sensations of wine developed in psychology, although these may also contain valuable insights into how brains react to and make sense of wine's chemical properties (Perullo, 2021; Shepherd, 2017; Siegrist and Cousin, 2009; Solomon, 1990).

Other work coming from STS includes Phillips (2016) on how tastes are 'assembled', and Pont and Thomas (2012) on the socio-technical networks that make wine happen. Such thematics resonate with approaches to wine developed in geography. Geography is perhaps the social science which engages most with wine matters, perhaps an unsurprising fact given the centrality of wine production to the agricultural and symbolic economies of major wine producing countries. French geographic studies have been particularly important in developing understandings of the historical development of wine-making in that country, with such major figures as Roger Dion (1959; also Delay and Chevallier, 2015; Dion and Timoner, 1994) and Jean-Robert Pitte (2000, 2013) profoundly contributing not only to analysis of the central role of wine in the French countryside, but also to shaping broader French public debates and self-understandings of the place of wine in the national culture and society (Dutton, 2019). 
In English-speaking geography, both Dan Stanislawski's (1975) and Hans de Blij’s (1983; also Hiner et al., 2014) work helped to set out wine as a major research agenda, as did Tim Unwin's (1991) magisterial overview of the long-term history of wine's changing geographic dynamics. This work has clear resonances with, and uses for, sociology, as it is not narrowly focused only on physical geography but on matters of social and cultural geography too, and with the socio-spatial aspects of wine, considered in a broad sense.

Contemporary studies of wine within geography are many and manifold (e.g. Dickenson and Salt, 1982; Dougherty, 2012; Jones, 2003; Sommers, 2008; Unwin, 2017), many providing interesting analyses of vexed issues of terroir (Barham, 2003; Gade, 2004; Moran, 1993;) and legal definition and protection thereof (Parrott et al., 2002), and also appreciating the role of such industrial phenomena as value chains, agro-industrial conventions, regional wine-making clusters, regulatory regimes, and forms of competition and collaboration between companies (Beebe et al, 2013; Guthey, 2008; Haughton and Browett, 1995; Patchell, 2008). There are also contributions to the subdisciplinary areas of economic geography (Cassi et al., 2012; Hayward and Lewis, 2008; Rainer, 2016, 2021; Turner, 2010;), human geography (Brabazon, 2014; Lagendijk, 2004), and cultural geography, which considers, among other things, representations of terroir matters in professional and popular media (Hill, 2018, 2021). Most geographical studies concern primarily the production and distribution of wine, although they have implications for consumption trends (Gwynne, 2008), especially in terms of Fairtrade and other ethical initiatives in locations like South Africa and Chile (Hastings, 2019; Herman, 2018, 2019). A particular focus of some economic geographers is on globalization of production methods and customer orientations (Rainer, 2016), especially in relation to the restructuring of wine making since the 1980s through processes of neo-liberalization (Corby, 2010). Overall, there is enough geographic study of wine to allow for some geographers to talk of the 'geography of wine' as a sub-field in its own right, in a way that sociologists cannot yet speak of regarding a 'sociology of wine' field.

The historical and economic foci of many geographers place their work close to that of economic historians (e.g., Anderson and Pinilla, 2019; Nelgen et al., 2017; Taplin, 2011) and political economists. In terms of the latter, the classical political economists of the $18^{\text {th }}$ and $19^{\text {th }}$ centuries often had interests in wine, especially in terms of how the collective reputation of a region could generate economic value for producers in that region (Chaikind, 2012). Karl Marx, critic of orthodox political economy, was highly attuned to wine matters, having grown up in the Mosel valley, and having witnessed the struggles of the local wine makers against the punitive policies of the authorities of the time, his reporting on such matters being one of his first endeavours in politicised journalism (Goldberg, 2013; Lubasz, 1976). Research today is particularly concerned to connect wine production and distribution to the broader dynamics of the global capitalist economy, with a focus on empires and imperial political economies in research dealing with times before WWII (Pinilla and Ayuda, 2002; Simpson, 2011), and dealing with trans-national neo-liberal political economy in the late 20 th and early $21^{\text {st }}$ centuries (Banks and Overton, 2010; Howson et al., 2019; Itçaina et al., 2016; Overton and Banks, 2015; Overton and Murray, 2013, 2016, 2017).

Political economy is in most cases closer to sociological considerations than is economics, although the sociologist of wine must attend to the work of economists too. Journals which traverse the space between academic economists concerned with wine and professionals in the wine industry include the Journal of Wine Economics, the Journal of Wine Research, and the International Journal of Wine Business Research. Major works in the selfstyled field of 'wine economics' include the following texts concerned with market dynamics, collective reputations, and the impact of wine critics on prices, among other economic issues (Ali et al., 2008; Anderson, 2004; Ashenfelter and Storchmann, 2010; Castriota, 2020; Castriota and Delmastro, 2015; Centonze, 2010; Cross et al., 2011; Duncan and Greenaway, 2008; Gergaud and Ginsburgh, 2008; Storchmann, 2012; Ugaglia and Cardebat, 2019). Some work in economics has clear sociological resonances (e.g., Diaz-Bone, 2017). There is also a plethora of wine research in the overlapping fields of business, management and organisational studies (Franco and Martins, 2020; Humphreys and Carpenter, 2018; Kwon and Constantinides, 2017; Simons and Roberts, 2008; Smith et al., 2013; Voronov et al., 2013; Zhao and Zhou, 2011).

Much of the wine marketing literature is aimed at wine industry audiences, creating knowledge that is meant to be useful for pragmatic marketing purposes, but some of it has clear sociological interest in terms of how producers aim to connect to consumer groups and in doing so create categories of consumers (Charters and Pettigrew, 2006; Lorey, 2021; Yang and Paladino, 2015), while also tending to present vineyards and wine making in highly idyllic ways which may erase uncomfortable social realities to do with labour exploitation and other problems in the wine industry (Beverland, 2005; Beverland and Luxton, 2005; Charters and Pettigrew, 2006). Some studies of wine tourism collude in such myth-making, while others may puncture it (Carlsen and Charters, 2006; Kruger et al., 2013; Ravenscroft and van Westering, 2001).

Wine is thoroughly tied up with legal phenomena. The disciplines of law and legal studies show how legal regulations and classifications operate at national, international, and transnational levels (Cavicchi, 2013; Maher, 2001). Legal disputes about who has the right to name particular wines in specific ways are common, and such struggles are bound up with trade disputes, both between countries and between trading blocs (Mahy and d'Ath, 2017; Robertson, 2009; Veseth, 2012). 
Wine is nothing if not highly political and often politicised, in various senses (Colman, 2008; Veseth, 2012). While the discipline of political science has barely touched upon wine matters, policy studies can yield insightful accounts of how law and politics interpenetrate in wine production (Roger, 2010). More common are analyses of the cultural politics of wine (Certomà, 2011). France is especially well covered in this regard (Barthel-Bouchier and Clough, 2005; Smith, 2016; Waters, 2010). A range of academic writings about French wine politics (Trubek, 2006) came out in the wake of the worldwide popularity and notoriety of Jonathan Nossiter's polemical documentary Mondovino (2004), which controversially portrayed a story of southern French resistants ranged against the foreign behemoths of the international wine industry. How wider political controversies feed into, and are represented through, wine, has been a recent focal point for scholars working in various disciplinary traditions (Handel et al., 2015; Monterescu and Handel, 2019).

The disciplines of archaeology and history traverse the social sciences and humanities. Archaeological work on the origins of wine has been pioneered in particular by McGovern (2003) and McGovern et al. (2017). With ancient history and classical studies, there is a long-standing scholarly engagement with wine matters (Brun, 2003; Dietler, 2006; Lissarrague, 2016; Lutz, 1922; Maniatis, 2013; Papakonstantinou, 2009; Russell, 2003; Sealey, 2009; Wilson, 2012;). ${ }^{1}$ This includes work which traces ancient legacies on modern drinking patterns, including the millennialong association of wine with civilization and beer with barbarity (Engs, 1995; Gautier, 1997; Nelson, 2014), which continues to resonate with present-day attempts to legitimize beer as being as serious a drink as is wine (Koontz and Chapman, 2019). Theology and religious studies offer materials which contribute to the long-term religious framing and uses of wine, especially in Christianity; Jesus famously turned water into wine, and in early Christianity he was often conflated with Dionysos, the Greek god of wine (Bacchiocchi, 2001; Friesen, 2014; Fuller, 1996; Inglis, 2022; Kreglinger, 2019; Younger, 1966).

Within historical studies of more recent times, historians tend to produce, on the basis of archival research, monographs concerned with wine in particular times and places. Post-medieval England and France are particularly well represented in this literature (Bohling, 2018; Campbell, 2004; Guy, 2003; Harding, 2019; Heath, 2014; Holt, 1993; Hori, 2008; Ludington, 2013; Parker, 2015; Smith, 2016; Whalen, 2009; White, 2017). Other locations covered by historians include various other European countries (Conca Messina et al., 2019), the trans-Atlantic wine trade (Hancock, 2009), the Americas (Cinotto, 2012; Hannickel, 2013; Hendricks, 2004; Huber, 2011; Peck, 2009; Pinney, 1989), Australia (Brady, 2018; McIntyre, 2012), South Africa (Fourie and Von Fintel, 2014; Nugent, 2011), and other locales (e.g., Pankhurst, 2006). The discipline of cultural history has also examined changing cultural representations of wine (Brennan, 1989; Classen, 2017; Garrier, 2002; Hilgard, 2008; Varriano, 2010).

The humanities disciplines offer a range of approaches to wine. Literary studies have considered the presence of wine in literature in various national contexts (Anderson, 2018; Bruera, 2013; Del Puppo, 2016; Mayer-Robin, 2008). Cultural studies yield critical readings of wine-related phenomena in ways which are familiar to cultural sociologists (Cappeliez, 2017; Dutton, 2020), while media studies concern the representation of wine across multiple media (Schirmer, 2014; Smith Maguire, 2019a; Smith Maguire and Lim, 2015). Linguistics and other disciplines concerned with language offer analyses of how wine vocabulary operates (Langlois et al., 2011; Lehrer, 1975; Lindstrom, 1975; Tiefenbacher and Townsend, 2019), phenomena which sociologists would want to connect more thoroughly to issues of social power and inequalities (Inglis, 2019a).

In terms of the natural and medical sciences, there are vast literatures in multiple fields. Medicine and public health consider the health impacts of wine drinking (Johansen et al, 2006), as do, in other ways, interdisciplinary alcohol studies (Törrönen and Maunu, 2017). The practices of viticulture, viniculture and oenology, and the sciences, such as microbiology, which underpin them, are also very significant areas of study (Belda et al., 2017; Matthews, 2016). There is also a large literature in environmental science, an especially crucial topic area as climate change increasingly changes established patterns of vine maintenance and wine making (Almaraz, 2015; Nicholas, 2015). Such changes have stimulated much debate about how to make the wine industry more ecologically and socially sustainable (Forbes et al., 2020).

Sociology can have multiple relationships with the disciplinary and sub-disciplinary formations and their respective literatures which have been indicated above. First, sociologists can draw on and refer to empirical data generated by them. Second, the best work in each area can serve as an inspiration for the formulation of specifically sociological questions about the sorts of wine-related phenomena other disciplinary specialists have already

\footnotetext{
${ }^{1}$ One of the greatest historians of Western antiquity, author of The History of the Decline and Fall of the Roman Empire, Edward Gibbon, was a very serious wine drinker. "A great deal too much wine”, in Gibbon's estimate, "was near two bottles apiece”, but he sometimes drank much more. When Gibbon went on his Grand Tour he exhibited a Jekyll and Hyde syndrome: the scholarly young man of fashion would change to one who, he confessed to his diary, was looked on "as a man who loved wine and dissipation" and who would, when outside of a couple of bottles of wine, indulge in "unparalleled impudence" with the more permissive ladies of Lausanne. Thus, early in life Gibbon became an alcoholic, and Madeira and plenty of it soon became essential for his health' (Foster, 1979: 1634).
} 
engaged with. Third, certain kinds of theory, which sociology shares with other disciplines, can be taken in more explicitly sociological directions, while forms of sociological theory hitherto barely applied to wine matters can be deployed, therefore extending the theoretical reservoir open to the emerging field of interdisciplinary wine studies. Fourth, sociology can both learn from and contribute to that area.

Fifth, wine today is usually examined within the standard conceptual, thematic, and methodological apparatuses of disciplines, each one processing wine matters in its customary ways, highlighting some phenomena, while underplaying or ignoring others. By and large, specialists from each discipline focus on those aspects of wine that one would expect them to focus on. Thus, where disciplinary orientations seem too narrow to capture the full range of possibilities inherent within a particular set of wine-related phenomena, sociology can extend the analytical purview of studies of such phenomena, in like manner to the way that both anthropology and economic sociology have broadened the purview of more narrowly focused studies of matters such as wine price formation.

Sixth, and more generally, despite the promising emergence of an interdisciplinary field of 'wine studies', that field remains largely organised in disciplinary terms. Today there is still too little truly trans-disciplinary thinking and research which brings together the diverse phenomena concerning the many and manifold aspects of wine, taken in all their abundance and plenitude. Sociology is well placed to encourage such thinking: after all, it is the social science that seeks to deal with all possible types of phenomena, be those referred to conventionally as 'cultural', 'political', 'economic', or whatever. Of course, there should be more sub-disciplinary studies of wine, by areas of sociology that already do so (such as economic and cultural sociologies) or could in future do so (political sociology, historical sociology, postcolonial sociology, sociology of ethnicity, sociology of genders and sexualities, and so on). All of that is necessary but not sufficient to develop a sociology of wine field and associated sociologies of wine in the plural.

There lies a potential in sociological thinking and research practice to try to connect as many different sorts of wine-related phenomena which until now have been left relatively disconnected and mainly dealt with in disciplinary and sub-disciplinary silos. Sociology's connective capacities can be deployed to bring together winerelated things that are usually, but unsatisfactorily, defined as either macro-, meso- or micro-level in nature. Illustrating how all of these may interpenetrate and inform the others can be sociology's over-riding concern. Connections must be made that range imaginatively across time and space (e.g. showing how the neo-liberalization of the wine-making regime in Chile has gone together with the cultivation of new drinking practices in Lapland). Sociological analysis of wine should be self-consciously cosmopolitan in cultural and geographical scope, and also deeply historical, ranging across the centuries, taking in not just very recent developments, but grasping the whole of wine history in its total 8,000-year span.

Both geography and anthropology have made strides in these sorts of directions, but sociology can aim to make such connections - especially those that are not obvious and may operate in more subterranean fashions - in its own distinctive ways too. That can and should be the ambition for those working sociologically on wine, while learning from wine at the same time, and thereby possibly challenging their own habituated ways of thinking and researching into the bargain.

This special issue aims at constructing a sociology of wine, just as, for example, a sociology of arts and artists had to be self-consciously constructed thirty years ago and more (Zolberg, 1990). We wish to explore what sociology as a discipline, and as a set of multiple, overlapping concerns, perspectives, and theorisations, can bring to the understanding of wine. 'Sociology' is a broad set of endeavours, with loose and porous boundaries to other disciplines. Still, we can inquire as to which sorts of added value sociology can bring to wine analysis. We can consider which types of phenomena may be understood more profoundly than before if they are subjected to sociological scrutiny. We may think about which connections and linkages can be made by sociology which have hitherto remained obscure or have been conceived of in other, non-sociological, terms. We can reflect on what happens when wine is, as it were, poured into a sociological decanter. We can see what transpires when sociological analysis is poured into wine. ${ }^{2}$

For the purposes of constructing a more capacious interface between wine and sociology than has existed before, we propose a research agenda which will in future involve providing multiple, possibly overlapping, and possibly contradictory, but still compelling, answers to the following four sets of questions:

\section{Theory, Foci, Methodology, and Methods}

a. Which resources, either more- or less well-established, in sociological theory (and in broader social and cultural theory, or any other kind of theory) can the sociology of wine draw upon, as well as contribute to and subject to critique?

b. Which units of analysis should the sociology of wine construct and deploy?

\footnotetext{
${ }^{2}$ Given mainstream Western sociology's roots in classical European philosophy, if sociology itself were to be de-Kanted, all
} that would be left would be some Hegelian sediments. 
c. Which methodological orientations, and which specific research methods, can the sociology of wine deploy, both in terms of more established and more novel orientations and techniques?

d. How might sociologists of wine carry out studies of wine-related phenomena on various scales ('local', 'subregional', 'regional', 'national', 'continental', etc. etc.)?

e. How can research projects carried out at various scales be connected?

f. How might comparative research be conceptualised and organised?

g. What might be the established and emerging areas of ethical concern that sociologists of wine must navigate in their research practice?

h. Which social, societal, cultural, political and economic wine-related phenomena should the sociology of wine be particularly concerned with today?

i. Which geographical areas (both 'real' and 'imagined'), social actors, social groups, and other sociological entities, should the sociology of wine study?

j. Which phenomena in wine industries, worlds and cultures are already quite well covered by analysts, either within or without sociology, and which phenomena are important but under-researched?

k. How might the sociology of wine draw upon, and contribute to, previous, current and future analyses of food and other drinks, both alcoholic (such as beer, including novel "craft" versions thereof) and nonalcoholic (including tea and coffee)?

\section{Disciplinarity and Beyond}

a. What would the (or a) core of a 'sociology of wine' look like and involve?

b. Is constructing such a core possible or desirable?

c. Who would construct it?

d. Who would challenge and critique it?

e. Should or can there be $a$ sociology of wine, or instead ought there it be multiple sociologies?

f. Should sociological analysis of wine be understood as sociology of wine, or rather, as Jennifer Smith Maguire's paper in this volume proposes, sociology from wine?

g. Is there a meaningful and/or productive difference between sociology (or sociologies) of wine, and wine sociology (or sociologies) and similar terms, such as oenological sociology?

h. How might sociology of wine relate to various established general sub-fields of sociology, such as cultural, economic, political, and health sociologies, as well as more bespoke areas, such as the sociologies of food, alcohol, agriculture, rurality, and so on?

i. Is an inter-, trans- or pan-disciplinary social science of wine possible, and if so, what is sociology's potential role(s) within that, as one specialism among others, or as a unifying and synthesizing exercise, or as something else?

j. Is it possible or worthwhile to create a synthetic and panoptic (social) science of wine in all its various aspects?

k. How can the sociology of wine make productive use of studies and approaches coming from other disciplines?

1. How can and should it work with scholars from other social science disciplines, as well as those from the humanities?

$\mathrm{m}$. How may the sociology of wine interact with diverse practitioners of the environmental and natural sciences, ranging from, for example, wine scientists to those concerned with climate change?

\section{Politics, in the Broadest Sense of the Term}

a. How might the sociology of wine connect wine-related phenomena to broader issues of sociological and political concern, such as power dynamics, inequalities, and exclusions based on a host of social factors (class, gender, ethnicity, locality, religion, sexualities, disabilities, etc. etc.)?

b. How might sociological accounts of wine and power relate to, overlap with, replicate, and differ from, accounts of power in wine industries, cultures, and worlds offered by other types of social scientists?

c. In what ways might the sociology of wine contribute to the broader politics of wine? Which wine-related groups might sociologists of wine wish to ally with, or set themselves against?

d. What may be the ways that sociologists of wine engage with more powerful and less powerful actors in wine industries, cultures, and fields, including industrial, political, and professional groups?

e. Is it possible or desirable for the sociology of wine to make value judgments, such as those concerning vexed issues like that of terroir (Teil, 2012), or of the alleged superiority of some wines or wine-producing areas over others? 


\section{Organization}

a. What might be the likely funding sources, and other forms of support, for sociological studies of wine, and how can funders be encouraged to take such research seriously?

b. How might international, cross-border and cross-regional cooperation among sociologists of wine, as well as with cognate others, be fostered and managed?

c. How can the sociology of wine be grown in and through journal publications, books and book series, blogging, vlogging, social media, and other means and mechanisms?

d. How should sociology contribute to, and learn from, interdisciplinary wine studies? Could sociology help transform that from an interdisciplinary formation to a transdisciplinary constellation?

*******

The papers in this special edition seek to answer some, but not all, of these questions. They may be understood as initial and tentative, but also imaginative and productive, attempts to start to fill out what sociology can say about wine, involving analyses that hopefully will be variously useful, thoughtful, and sometimes striking. While each specific contribution studies, and proposes the study of, wine in different ways, they all in one way or another point out that wine is neither fixed nor stable. It is possessed of multiple qualities and affordances, and it is subject to many different ways of bringing it into being and putting it to work, while at the same it also makes things happen and moves many things around.

The overview piece by David Inglis begins with reflections on the relations between the sociologist and wine as the object of study. Drawing on parallels with the sociologies of music and of art, Inglis depicts some of the pitfalls involved when the sociologist has a love of wine but must submit it to the vagaries of sociological analysis. He then considers the manifold processes that wine is caught up in, and which it makes possible, suggesting that these should be scrutinized in very long-term historical perspective. Focusing on the -ization processes that have been at the conceptual core of sociology since the time of the classical sociologists, Inglis reflects on how sociology can provide a capacious vision of the whole history of wine, and across the whole range of societies where it has been made and drunk. On his view, a sociology of wine needs to be highly ambitious in terms of trying to capture the interplay between factors of all sorts, factors that other disciplines typically treat in isolation. More hidden connections and resonances are thereby brought to the fore that might otherwise not have captured the attention of the more narrowly focused analyst. In this understanding, sociology of wine is a historical sociology in a deep sense, covering not decades or centuries only but millennia, and casting its eye over the whole planet, tracking wine's mutations as it travels hither and thither across the ages. On this view, sociology provides a generalizing science of wine in ways that other disciplines cannot or will not attempt.

Jennifer Smith Maguire is likewise focused on various processes to do with wine, in an approach she calls vina aperta, a sociology from wine. Her argument is that three kinds of foci and perspectives are needed for a rounded sociological understanding of wine. First, wine must be understood as processual, involving both long-term processes and specific moments within those. Second, wine is interconnected with(in) the world, in the sense that its autonomy as a system is always relative, and it involves a diversity of heterogenous connections between humans, things, and multiple materials. Third, wine is also interdependent, with the physical world, between humans, and within an individual human and their embodied senses. In her approach, Smith Maguire considers it essential that a sociology from wine avoids the traps of limitations and closedness that the creation of any sub-field in academic research is prone to. She thereby rejects the idea of a sociology of wine. She stresses that wine $-\mathrm{a}$ manifestly interdependent field - may be ill suited for limited sociological or historical approaches. Thus, she agrees in some ways with Inglis, but differs in other regards, for what she rejects - a sociology of wine - he embraces. (Let us hope that this dispute can be resolved amicably over a bottle of wine, the precise kind being chosen consensually between the disputants.)

Anna-Mari Almila's starting point also stresses openness and flexibility in analysis, but her focus is very different. She considers how wine has been and remains highly gendered in various ways. In a methodologically flexible approach - namely using different illuminative vignettes to explore the deeply engrained nature of gender boundaries and constructions regarding wine - she illuminates how matters which are seemingly trivial may bring such structures more clearly into view. Dealing with topics ranging from rosé wine to menstruation, and from musical hall songs to perfume, Almila takes apparently trivial phenomena and uses them, in the manner of Georg Simmel, to draw out much wider patterns of significance which reoccur throughout history, although with novel features as time goes on. While wine's alcoholic character is central to its perceived 'danger' as regards gender boundaries, wine is also always much more than just alcohol. It is deeply symbolic, powerful, and also vulnerable to gendered forms of pollution. In Almila's Mary Douglas-inspired analysis, wine's gendered cultures are shown to variously demonstrate, challenge, adapt, re-construct, and accommodate existing and emerging social and cultural systems of gender.

The recent rise of China as a major power, both in the buying of foreign wines (Capitello et al., 2016; Ho, 2019; Kjellgren, 2019; Zhang, 2018), and in the development of a national industry to meet local demands (Howson and 
Ly, 2020; Zheng, 2019), has been well documented by authors from various disciplinary perspectives over the last decade. Building on research about wine in Hong Kong (Ho, 2021b), Hang Kei Ho endeavours to widen the analytical lens somewhat. His focus is not only on China, which has risen to spectacular levels of prominence in various wine-related matters over the last two decades, but also East Asia more widely. He considers wine in the wider alcohol cultures of the region, and also as a luxury product which has become ever more important in the societies in question. He recognizes a number of influences that have led to the emergence of wine consumership in East Asia, such as forms of European and Asian colonialism, Westernization processes, influential ideas regarding the high cultural status of European wine in general and French wine especially, the increasing disposable economic capital of the higher reaches of the middle classes and social elites, the aspirational cultural capital of more middling players, and the activities of local cultural mediators in educating the expanding ranks of willing and curious consumers. He stresses that despite the often-mentioned changes in wine cultures in East Asia, many traditions and beliefs nevertheless survive, shaping the variety of local consumption habits.

Geneviève Teil's previous work, deploying and extending pragmatist sociology and resonating with thematics of Actor-Network Theory, has already yielded highly original accounts of both the collective elaboration of terroir by winemakers and multiple other actors (Teil, 2012), and also of the practices of wine appreciation (Teil, 2021; see also Teil et al., 2011). Her article shifts away from conventional foci concerning the wine economy and wine's various economic regimes. She argues that wine is not just one kind of an economic market, but instead there are two kinds of market logics at play, each targeting consumers who have differently operating tastes and taste preferences. She starts from the understanding that 'quality' is an agreement rather than an absolute factor, and that quality indicators and guarantees, such as those elaborated in and through the French AOC system, are not absolute but rather operate in a deeply contested terrain of understandings of quality. In this sociological pragmatist approach, which examines how wine phenomena emerge through intertwining processes, Teils looks at winemakers' understandings of consumer tastes and desires, and the economic consequences thereof. She concludes that while a 'standard' wine market regime operates with notions and practices of stabilized quality, involving constant monitoring of customer tastes, and discreetly handled changes to wine tastes and styles, another market regime also exists. This is 'exploratory' and is based around variety, change and the constant emergence of new customer tastes and styles, serving committed but open-minded wine enthusiasts. She ends her article with some reflections as to what extent wine production can be said to have gone through processes of 'artification', where the winemaker emerges as an artist-like creator of ever transforming innovative wines and winemaking.

Peter Howland - in an article introducing a highly innovative, and greatly amusing, way of writing about wine, which takes the form of a self-interview - argues that sociologists should not forget 'the obvious' when analyzing wine, especially in terms of economic matters. Such an ignoring of blatant economic forces, he claims, often accepts capitalism as a de facto unchanging and unchallengeable condition, rather than critically analyzing and evaluating the extremely unequal economic and labour conditions established in the (capitalist) wine industry worldwide. He also recognizes further issues to do with sociological approaches to wine. The research focus often is on small-scale production, which may involve apparently charming people making lovely wines. The researcher's need to gain access to the field - in this case, the vineyard and so-called 'boutique' winery - may unintentionally end up taking the focus away from the more obviously capitalist-industrial end of the wine-making scale, while also hiding multiple economic, labour exploitation, and ecological problems persistent also in independent small-scale production. For any industry-facing wine research, identifying and overcoming these kinds of problems are highly relevant. Howland suggests that sociologists should take care to 'follow the money', paying attention especially to luxury wine production (as does Ho's paper), but also to the economic failure of some vineyards and wineries. He also recognizes that while economy must be at the heart of sociological research on wine, wine is nevertheless a set of material and scientific phenomena too, and these must not be forgotten by the sociological investigator. Grape wine is both a very specific thing, a world unto itself, a domain interpenetrated in many ways by globalized capitalism and its various attendant ills, and all sides of it should be explored by the sociologist.

$* * * * * * *$

We hope that the reader enjoys the special issue as a whole, as well as its constituent parts. If you read it while sipping a glass of wine, that would seem an appropriate response to what we have offered to you: a series of texts which request that you savour them and that you hopefully extract some forms of productive - or indeed constructive (Douglas, 1987) - pleasure from them.

\section{REFERENCES}

Ali, H. H., Lecocq, S. and Visser, M. (2008). The impact of gurus: Parker grades and en primeur wine prices. The Economic Journal, 118(529), F158-F173. https://doi.org/10.1111/j.1468-0297.2008.02147.x

Allen, M. P. and Germov, J. (2011). Judging taste and creating value: The cultural consecration of Australian wines. Journal of Sociology, 47(1), 35-51. https:/ / doi.org/10.1177/1440783310380988

$10 / 21$

C) 2021 by Author/s 
Allholf, F. (ed) (2007). Wine and Pbilosophy: A Symposium on Thinking and Drinking. Oxford: Wiley-Blackwell.

Almaraz, P. (2015). Bordeaux wine quality and climate fluctuations during the last century. Climate Research, 64(3), 187-199. https://doi.org/10.3354/cr01314

Almila, A. (2019). Wine, women and globalization: The case of female sommeliers, in D. Inglis and A. Almila (eds), The Globalization of Wine (pp. 191-212). London: Bloomsbury. https://doi.org/10.5040/9781474265027.ch-011

Almila, A. (2021). A wine flight of gendered sociologies: Vignettes of (apparent) trivialities. Journal of Cultural Analysis and Social Change, 6(2), 11. https://doi.org/10.20897/jcasc/11449

Almila, A. and Inglis, D. (2022). Threats of pleasure and chaos: Wine and gendered social order, in S. Charters, M. Demossier, J. Dutton, G. Harding, J. Smith Maguire, D. Marks and T. Unwin (eds), The Routledge Handbook of Wine and Culture (pp. 311-319). London: Routledge.

Anderson, K. (ed) (2004). The World's Wine Markets: Globalization at Work. Cheltenham: Edward Elgar. https://doi.org/10.4337/9781845420765

Anderson, K. and Pinilla, V. (eds) (2019). Wine Globalization: A New Comparative History. Cambridge: Cambridge University Press. https:// doi.org/10.1017/9781108131766

Anderson, V. D. (2018). Mapping Modiano’s Bordeaux. Yale French Studies, 133, 81-93.

Ashenfelter, O. and Storchmann, K. (2010). Measuring the economic effect of global warming on viticulture using auction, retail, and wholesale prices. Review of Industrial Organization, 37(1), 51-64. https://doi.org/10.1007/ s11151-010-9256-6

Atkin, T. and Thach, L. (2012). Millennial wine consumers: Risk perception and information search. Wine Economics and Policy, 1(1), 54-62. https:// doi.org/10.1016/j.wep.2012.08.002

Atkin, T., Nowak, L. and Garcia, R. (2007). Women wine consumers: Information search and retailing implications. International Journal of Wine Business Research, 19(4), 327-339. https: / / doi.org/10.1108/17511060710837454

Bacchiocchi, S. (2001). Wine in the Bible. Berrien Springs: Biblical Perspectives.

Banks, G. and Overton, J. (2010). Old world, new world, third world? Reconceptualising the worlds of wine. Journal of Wine Research, 21(1), 57-75. https://doi.org/10.1080/09571264.2010.495854

Barber, N., Almanza, B. A. and Donovan, J. R. (2006). Motivational factors of gender, income and age on selecting a bottle of wine. International Journal of Wine Marketing, 18(3), 218-32. https://doi.org/10.1108/ 09547540610704774

Barham, E. (2003). Translating terroir: The global challenge of French AOC labelling. Journal of Rural Studies, 19(1), 127-138. https://doi.org/10.1016/S0743-0167(02)00052-9

Barthel-Bouchier, D. and Clough, L. (2005). From Mondavi to Depardieu: The global/local politics of wine. French Politics, Culture \& Society, 23(2), 71-90. https://doi.org/10.3167/153763705780980029

Barthes, R. (2013 [1957]). Wine and milk, in Mythologies (pp. 58-60). New York: Hill and Wang.

Beckert, J., Rössel, J. and Schenk, P. (2017). Wine as a cultural product: Symbolic capital and price formation in the wine field. Sociological Perspectives, 60(1), 206-222. https://doi.org/10.1177/0731121416629994

Beebe, C., Haque, F. Jarvis, C., Kenney, M. and Patton, D. (2013). Identity creation and cluster construction: The case of the Paso Robles wine region. Journal of Economic Geography, 13, 711-740. https://doi.org/10.1093/jeg/ lbs033

Belda, I., Zarraonaindia, I., Perisin, M., Palacios, A. and Acedo, A. (2017). From vineyard soil to wine fermentation: Microbiome approximations to explain the "terroir" concept. Frontiers in Microbiology, 8, Article 821. https://doi.org/10.3389/fmicb.2017.00821

Benjamin, B. A. and Podolny, J. M. (1999). Status, quality, and social order in the California wine industry. Administrative Science Quarterly, 44(3), 563-589. https:/ / doi.org/10.2307/2666962

Berkowitz, N. (2014). The Winemaker's Hand: Conversations on Talent, Technique, and Terroir. New York: Columbia University Press. https://doi.org/10.7312/berk16756-013

Beverland, M. and Luxton, S. (2005). Managing integrated marketing communication (IMC) through strategic decoupling. Journal of Advertising, 34(4), 103-116. https:/ / doi.org/10.1080/00913367.2005.10639207

Beverland, M. B. (2005). Crafting brand authenticity: The case of luxury wines. Journal of Management Studies, 42(5), 1003-1029. https://doi.org/10.1111/j.1467-6486.2005.00530.x

Black, R. E. and Ulin, R. C. (eds) (2013). Wine and Culture: Vineyard to Glass. London: Bloomsbury. https://doi.org/10.5040/9781350042254

Bohling, J. (2018). The Sober Revolution: Appellation Wine and the Transformation of France. Cornell: Cornell University Press. https://doi.org/10.7591/9781501716065

Bourdieu, P. (1984). Distinction: A Social Critique of the Judgment of Taste. London: Routledge.

Brabazon, T. (2014). Colonial control or terroir tourism? The case of Houghton's White Burgundy. Human Geographies, 8(2),17-33. https://doi.org/10.5719/hgeo.2014.82.17

Brady, M. (2018). Teaching 'Proper' Drinking? Clubs and Pubs in Indigenous Australia. Canberra: ANU Press. https://doi.org/10.22459/CAEPR39.12.2017 
Brennan, T. (1989). Towards the cultural history of alcohol in France. Journal of Social History, 23(1), 71-92. https://doi.org/10.1353/jsh/23.1.71

Brighenti, A. M. (2018). Tasting wine making territories, in A. Pavoni, D. Mandic, C. Nirta and A. Philippopo (eds), Taste (pp. 145-174). University of Westminster Press. https://doi.org/10.16997/book21.e

Bruera, M. (2013) Mapping the Tasteland: Explorations in Food and Wine in Argentinean and European Culture. New York: Peter Lang. https:// doi.org/10.3726/978-3-0353-0554-8

Brun, J.-P. (2003). Le vin et l'Huile dans la Méditerranée Antique. Viticulture, Oléiculture et Procédés de Transformation [Wine and Oil in the Ancient Mediterranean. Viticulture, Oléiculture and Transformation Processes]. Paris: Errance.

Bryant, L. and Garnham, B. (2014). The embodiment of women in wine: Gender inequality and gendered inscriptions of the working body in a corporate wine organization. Gender, Work and Organization, 21(5), 411 426. https://doi.org/10.1111/gwao.12045

Campbell, C. (2004). Phylloxera: How Wine was Saved for the World. London: Harper-Perennial.

Capitello, R., Charters, S., Menival, D. and Yuan, J. (2016). The Wine Value Chain in China. Amsterdam: Chandos Publishing.

Cappeliez, S. (2017). How well does terroir travel? Illuminating cultural translation using a comparative wine case study. Poetics, 65, 24-36. https://doi.org/10.1016/j.poetic.2017.10.002

Carlsen. J. and Charters, S. (eds) (2006). Global Wine Tourism. Wallingford: CABI.

Carter, E. (2019). From myths to markets: Power, institutions and the reification of imagined histories. European Journal of Sociology, 60(2), 211-236. https:// doi.org/10.1017/S0003975619000110

Cassi, L., Morrison, A. and Ter Wal, A. L. J. (2012). The evolution of trade and scientific collaboration networks in the global wine sector: A longitudinal study using network analysis. Economic Geography, 88(3), 311-334. https://doi.org/10.1111/j.1944-8287.2012.01154.x

Castriota, S. (2020). Wine Economics. Cambridge: MIT Press. https://doi.org/10.7551/mitpress/11106.001.0001

Castriota, S. and Delmastro, M. (2015). The economics of collective reputation: Evidence from the wine industry. American Journal of Agricultural Economics, 97(2), 469-489. https://doi.org/10.1093/ajae/aau107

Centonze, A. L. (2010). Transitional cluster development: A case study from the New York wine industry. Economic Development Quarterly, 24(3), 251-260. https://doi.org/10.1177/0891242410362897

Certomà, C. (2011). Standing-up vineyards: The political relevance of Tuscan wine production. Environment and Planning D: Society and Space, 29(6), 1010-1029. https://doi.org/10.1068/d2410

Chaikind, S. (2012). The role of viticulture and enology in the development of economic thought: How wine contributed to modern economic theory. Journal of Wine Economics, 7(2), 213-225. https://doi.org/10.1017/ jwe.2012.17

Charters, S. (2006). Wine and Society: The Cultural and Social Context of a Drink. London: Routledge. https://doi.org/10.4324/9780080458038

Charters, S., Demossier, M., Dutton, J., Harding, G., Marks, D., Smith Maguire, J. and Unwin, T. (eds) (2022). The Routledge Handbook of Wine and Culture. London: Routledge.

Charters, S. and Pettigrew, S. (2006). Conceptualizing product quality: The case of wine. Marketing Theory, 6(4), 467483. https:// doi.org/10.1177/1470593106069932

Chauvin, P.-M. (2010). Le Marché des Réputations: Une Sociologie du Monde des V ins de Bordeaux [The Reputation Market: A Sociology of the World of the Wines of Bordeaux]. Bordeaux: Editions Féret.

Chiffoleau, Y. and Laporte, C. (2006). Price formation: The case of the Burgundy wine market. Revue Française de Sociologie, 47, 157-182. https://doi.org/10.3917/rfs.475.0157

Cinotto, S. (2012). Soft Soil, Black Grapes. New York: NYU Press. https://doi.org/10.18574/nyu/ 9780814717387.001.0001

Classen, A. (2017). Wine, drunkenness, morality, and satire in Der Wiener Meerfahrt. Neuphilologische Mitteilungen, 118(2), 263-278.

Colman, T. (2008). Wine Politics. Berkeley: University of California Press. https://doi.org/10.1525/9780520934733

Conca Messina, S. A., Le Bras, S., Tedeschi, P. and Piñeiro, M. V. (eds) (2019). A History of Wine in Europe, 19th to $20^{\text {th }}$ Centuries, Volume I: Winegrowing and Regional Features. Basingstoke: Palgrave. https://doi.org/10.1007/978-3030-27772-7

Corbeau, J.-P. (2004). Réflexions sociologiques 'en vrac' sur le vin [Sociological reflections 'in bulk' on wine]. Anthropology of Food, 3. https://doi.org/10.4000/aof.243

Corby, J. H. K. (2010). For members and markets: Neoliberalism and cooperativism in Mendoza's wine industry. Journal of Latin American Geography, 9(2), 27-47. https://doi.org/10.1353/lag.2010.0002

Crenn, C. (2015). Ethnic identity, power, compromise, and territory, in J. MacClancy (ed), Alternative Countrysides (pp. 61-81). Manchester: Manchester University Press.

Cross, R., Plantinga, A. J. and Stavins, R. N. (2011). What is the value of terroir? The American Economic Review 101(3), 152-156. https://doi.org/10.1257/aer.101.3.152 
Dans, E. P., Gonzálaz, P. A. and Vázquez, A. M. (2019). Taste and knowledge: The social construction of quality in the organic wine market. Human Ecology, 47, 135-143. https:// doi.org/10.1007/s10745-019-0051-1

de Benedittis, M. (2019). Expert wine tasting as a social practice: An enactive ethnography. Sociologica, 13(3), 135147.

de Blij H. J. (1983). Wine: A Geographic Appreciation. Totowa: Rowman and Littlefield.

Del Puppo, D. (2016). Nourishment and nature in Leopardi. Italica, 93(4), 693-704.

Delay, É. and Chevallier, M. (2015). Roger Dion, toujours vivant! [Roger Dion, still alive !]. Cybergeo: European Journal of Geography, 391-406. https://doi.org/10.4000/cybergeo.26961

Demossier, M. (1997). Producing tradition and managing social changes in the French vineyards: The circle of time in Burgundy. Ethnologia Europea, 27(1), 29-47. https://doi.org/10.16995/ee.865

Demossier, M. (2005). Consuming wine in France: The 'wandering' drinker and the 'vin-anomie', in T. Wilson (ed), Drinking Cultures (pp. 129-154). Oxford: Berg.

Demossier, M. (2010). Wine Drinking Culture in France: A National Myth or a Modern Passion. Cardiff: University of Wales Press.

Demossier, M. (2011). Beyond 'terroir': Territorial construction, hegemonic discourses, and French wine culture. The Journal of the Royal Anthropological Institute, 17(4), 685-705. https:/ /doi.org/10.1111/j.1467-9655.2011.01714.x

Demossier, M. (2013). Following Grands Crus: Global markets, transnational histories and wine', in R. E. Black and R. C. Ulin (eds), Wine and Culture: Vineyard to Glass (pp. 183-200). London: Bloomsbury. https:// doi.org/10.5040/9781350042254.ch-010

Demossier, M. (2018). Burgundy: A Global Anthropology of Place and Taste. Oxford: Berghahn. https://doi.org/10.2307/j.ctvw04ffz

Diaz-Bone, R. (2005). Strukturen der weinwelt und der weinerfahrung [Structures of the world of wine and the wine experience]. Sociologia Internationalis, 43(1/2), 25-57.

Diaz-Bone, R. (2017). Classifications, quantifications and quality conventions in markets - perspectives of the economics of convention. Historical Social Research / Historische Sozialforschung, 42(1), 238-262.

Dickenson, J. P. and Salt, J. (1982). In vino veritas: An introduction to the geography of wine. Progress in Human Geography, 6(2), 159-189. https://doi.org/10.1177/030913258200600201

Dietler, M. (2006). Alcohol: Anthropological/archaeological perspectives. Annual Review of Anthropology, 35, 229249. https://doi.org/10.1146/annurev.anthro.35.081705.123120

Dion, R. (1959). Histoire de la Vigne et du Vin en France: Des Origines au XIXe siècle [History of Vine and Wine in France: From the Origins to the 19th Century]. Paris: Clavreuil.

Dion, R. and Timoner, K. I. (1994). Introduction to the history of viticulture in France. Journal of Wine Research, 5(3), 215-224. https://doi.org/10.1080/09571269408718004

Domingos, N. (2016). The market as mediator. Gastronomica, 16(3), 31-43. https://doi.org/10.1525/ gfc.2016.16.3.31

Dougherty, P. H. (ed) (2012). The Geography of Wine. Dordrecht: Springer. https://doi.org/10.1007/978-94-0070464-0

Douglas, M. (ed) (1987). Constructive Drinking: Perspectives on Drinking from Anthropology. New York: Cambridge University Press.

Ducker, J. (2011). Teaching wine: Tasting educated tastes, in J. Strong (ed), Food, Drink, and Connoisseur Culture (pp. 105-120). University of Nebraska Press. https:// doi.org/10.2307/j.ctt1df4fx 7.8

Duncan, A. and Greenaway, D. (2008). The economics of wine - introduction. The Economics Journal, 118(529), F137-F141. https://doi.org/10.1111/j.1468-0297.2008.02145.x

Dutton, J. (2019). Geographical turns and historical returns in narrating French wine culture. Global Food History, 5(1-2), 113-131. https://doi.org/10.1080/20549547.2019.1570781

Dutton, J. (2020). Wine in Houellebecq: Cultural transgression or literary device? French Cultural Studies, 31(1), 73 90. https://doi.org/10.1177/0957155819893586

Dutton, J. and Howland, P. J. (eds) (2019). Wine, Terroir and Utopia. Abingdon: Routledge. https://doi.org/10.4324/ 9780429492471

Engs, R. (1995). Do traditional Western European drinking practices have origins in antiquity? Addiction Research 2(3), 227-239. https://doi.org/10.3109/16066359509005208

Estreicher, S. K. (2006). Wine: From Neolithic Times to the 21st Century. New York: Algora.

Fischler, C. (1999). Du Vin. Paris: Odile Jacob

Fitzmaurice, C. (2017). How rosé became high class: Categorical divestment and evaluation. Poetics, 61(1), 1-13. https://doi.org/10.1016/j.poetic.2016.10.006

Forbes, S. L., De Silva, T.-A. and Gilinsky, A. (eds) (2020). Social Sustainability in the Global Wine Industry. Basingstoke: Palgrave. https://doi.org/10.1007/978-3-030-30413-3 
Foster, W. D. (1979) Edward Gibbon's health. British Medical Journal, 2(6205), 1633-1635. https:/ / doi.org/10.1136/ bmj.2.6205.1633

Fourcade, M. (2012). The vile and the noble: On the relationship between natural and social classifications in the French wine world. The Sociological Quarterly, 53, 524-545. https://doi.org/10.1111/j.1533-8525.2012.01248.x

Fourie, J. and von Fintel, D. (2014). Settler skills and colonial development: The Huguenot wine makers in eighteenth-century Dutch South Africa. The Economic History Review, 67(4), 932-963. https://doi.org/10.1111/ 1468-0289.12033

Franco, M. and Martins, R. (2020). The role of networks in the internationalization process of small- and mediumsized enterprises in the wine-producing sector. Global Business Review, First published July 24, 2020. https://doi.org/10.1177/0972150920927373

Friesen, C. J. P. (2014). Dionysus as Jesus: The incongruity of a love feast in Achilles Tatius's Lencippe and Clitophon 2.2. Harvard Theological Review, 107(2), 222-240. https://doi.org/10.1017/S0017816014000224

Fuller, R. C. (1996). Religion and Wine. Knoxville: University of Tennessee Press.

Gade, D. W. (2004). Tradition, territory, and terroir in French viniculture. Annals of the Association of American Geographers, 94(4), 848-867.

Garrier, G. (2002). Histoire Sociale et Culturelle du Vin [Social and Cultural History of Wine]. Paris: Larousse.

Gautier, J.-F. (1997). La Civilisation du Vin [The Civilization of Wine]. Paris: Presses Universitaires de France.

Gergaud, O. and Ginsburgh, V. (2008). Natural endowments, production technologies and the quality of wines in Bordeaux: does terroir matter? The Economic Journal, 118(529), F142-F157. https://doi.org/10.1111/j.14680297.2008.02146.x

Germov, J. (2017). The changing global taste for wine: An historical sociological perspective, in J. Germov and L. Williams (eds), A Sociology of Food and Nutrition (pp. 335-355). Melbourne: Oxford University Press.

Goldberg, K. D. (2013). Reaping the Judenfrage: Jewish wine merchants in central Europe before World War I. Agricultural History, 87(2), 224-245. https:/ / doi.org/10.3098/ah.2013.87.2.224

Groves, R., Charters, S. and Reynolds, C. (2000). Imbibing, inscribing, integrating and imparting: A taxonomy of wine consumption practices. Journal of Wine Research, 11, 209-222. https://doi.org/10.1080/713684235

Guthey, G. T. (2008). Agro-industrial conventions: Some evidence from Northern California's wine industry. The Geographical Journal, 174(2), 138-148. https://doi.org/10.1111/j.1475-4959.2008.00275.x

Guy, K. M. (2003). When Champagne Became French: Wine and the Making of a National Identity. Baltimore: Johns Hopkins University Press.

Guy, K. M. (2019) Selling the French past, selling wine, and erasing labor from terroir. Global Food History, 5(1-2), 98. https://doi.org/10.1080/20549547.2019.1539816

Gwynne, R. N. (2008). UK retail concentration, Chilean wine producers and value chains. The Geographical Journal, 174(2), 97-108. https://doi.org/10.1111/j.1475-4959.2008.00276.x

Haddour, A. (2009). Bread and wine: Bourdieu's photography of colonial Algeria. The Sociological Review, 57(3), 385405. https:// doi.org/10.1111/j.1467-954X.2009.01846.x

Hampton, R. (2012). The vines that bind: Wine's unifying qualities. Qualitative Inquiry, 18(10), 852-861. https://doi.org/10.1177/1077800412456961

Hancock, D. (2009). Oceans of Wine: Madeira and the Emergence of American Trade and Taste. New Haven: Yale University Press.

Handel, A., Rand, G. and Allegra, M. (2015). Wine-washing: Colonization, normalization, and the geopolitics of terroir in the West Bank's settlements. Environment and Planning A: Economy and Space, 47(6), 1351-1367. https://doi.org/10.1177/0308518X15594917

Hannickel, E. (2013). Empire of Vines. Philadelphia: University of Pennsylvania Press. https://doi.org/10.9783/ 9780812208900

Harding, G. (2019). Inventing tradition and terroir: The case of Champagne in the late nineteenth century, in J. Dutton and P. J. Howland (eds), Wine, Terroir and Utopia (pp. 93-110). Abingdon: Routledge. https://doi.org/10.4324/9780429492471-6

Harvey, M, White, L. and Frost, W. (eds) (2014). Wine and Identity: Branding, Heritage, Terroir. London: Routledge. https://doi.org/10.4324/9780203067604

Hastings, T. (2019). Leveraging Nordic links: South African labour's role in regulating labour standards in wine global production networks. Journal of Economic Geography, 19(4), 921-942. https:// doi.org/10.1093/jeg/lbz010

Haughton, G. and Browett, J. (1995). Flexible theory and flexible regulation: Collaboration and competition in the McLaren Vale wine industry in South Australia. Environment and Planning A: Economy and Space, 27(1), 41-61. https://doi.org/10.1068/a270041

Hayward, D. and Lewis, N. (2008). Regional dynamics in the globalising wine industry: The case of Marlborough, New Zealand. The Geographical Journal, 174(2), 124-137. https:// doi.org/10.1111/j.1475-4959.2008.00279.x 
Heath, E. (2014). Wine, Sugar, and the Making of Modern France. Cambridge: Cambridge University Press. https://doi.org/10.1017/CBO9781107707498

Hendricks, R. (2004). Viticulture in El Paso del Norte during the colonial period. Agricultural History, 78(2), 191 200. https://doi.org/10.1525/ah.2004.78.2.191

Hennion, A. (2007). Those things that hold us together: Taste and sociology. Cultural Sociology, 1(1), 97-114. https:// doi.org/10.1177/1749975507073923

Herman, A. (2018). Assembling fairtrade: Practices of progress and conventionalization in the Chilean wine industry. Environment and Planning A: Economy and Space, 51(1), 51-68. https://doi.org/10.1177/ $0308518 X 18805747$

Herman, A. (2019). Asymmetries and opportunities: Power and inequality in Fairtrade wine global production networks. Area, 51(2), 332-339. https://doi.org/10.1111/area.12467

Herzog, B. (2020). Vino y Sociedad: Una Invitación a la Sociologia del Placer [Wine and Society: An Invitation to the Sociology of Pleasure]. València: Institució Alfons el Magnànim Centre Valencià d' Estudis i d' Investigació Diputació de València.

Hilgard, P. (2008). Sage Mir, Welchen Wein Du trinkst ... Die neue Gesellschaft der Weintrinker, im Spiegel der Kulturgeschichte [Tell Me What Wine You Dink... The New Society of Wine Drinkers, in the Mirror of Cultural History]. Dreieich: Verlag Kornmayer.

Hill, R. (2018). Staging a nation's culinary geography at the Salon de l'Agriculture. Cultural Geographies, 25(4), 643-649. https://doi.org/10.1177/1474474018778563

Hill, R. (2021). 'Le terroir, c'est la vie': Re-animating a concept among Burgundy's wine producers. Environment and Planning E: Nature and Space, First Published 25 Jan 2021. https://doi.org/10.1177/2514848621989610

Hiner, C. C., Townsend, C. C. and Lavy, B. L. (2014). Harm J. de Blij's 1983 Wine: A geographic appreciation. Progress in Physical Geography, 38(5), 674-684. https://doi.org/10.1177/0309133314540691

Ho, H. K. (2019). The globalization of the wine industry in Hong Kong: A local and global perspective, in D. Inglis and A.-M. Almila (eds), The Globalization of Wine (pp. 133-150). London: Bloomsbury. https://doi.org/10.5040/9781474265027.ch-008

Ho, H. K. (2021a). Twenty-first century wine consumption trends in East Asia: History, luxury and transformation, Journal of Cultural Analysis and Social Change, 6(2), 12. https://doi.org/10.20897/jcasc/11450

Ho, H. K. (2021b). Why has wine consumption become popular in Hong Kong? Introducing a new sociocultural paradigm of traditional, aspiring and creative drinkers. Asian Antbropology, 20(4), 248-268. https://doi.org/10.1080/1683478X.2021.1936731

Ho, S.-L. (2015). 'License to drink': White-collar female workers and Japan's urban night space. Ethnography, 16(1), 25-50. https://doi.org/10.1177/1466138113506632

Holt, M. P. (1993). Wine, community and reformation in sixteenth-century Burgundy. Past \& Present, 138, 58-93. https://doi.org/10.1093/past/138.1.58

Hori, M. (2008). The price and quality of wine and conspicuous consumption in England 1646-1759. The English Historical Review, 123(505), 1457-1469. https://doi.org/10.1093/ehr/cen277

Howland, P. J. (2013). Distinction by proxy: The democratization of fine wine. Journal of Sociology, 49(2-3), 325-340. https://doi.org/10.1177/1440783313481746

Howland, P. J. (ed) (2022). Wine and the Gift. London: Routledge.

Howson, C. and Ly, P. (2020). Adventures on the China Wine Trail. New York: Rowman and Littlefield.

Howson, K., Murray, W. and Overton, J. (2019). Certified utopia: Ethical branding and the wine industry of South Africa, in J. Dutton and P. J. Howland (eds), Wine, Terroir and Utopia (pp. 145-162). Abingdon: Routledge. https://doi.org/10.4324/9780429492471-9

Huber, T. P. (2011). Wine: An American Provence. Boulder: University Press of Colorado.

Humphreys, A. and Carpenter, G. S. (2018). Status games: Market driving through social influence in the U.S. wine industry. Journal of Marketing, 82(5), 141-159. https:// doi.org/10.1509/jm.16.0179

Inglis, D. (2019a). Mutating and contested languages of wine: Heard on the grapevine, in S. D. Brunn and R. Kehrein (eds), Handbook of the Changing World Language Map (pp. 4033-4058). Dordrecht: Springer. https://doi.org/10.1007/978-3-030-02438-3_205

Inglis, D. (2019b). Wine globalization: Longer-term dynamics and contemporary patterns, in D. Inglis and A.-M. Almila (eds), The Globalization of Wine (pp. 21-46). London: Bloomsbury. https://doi.org/10.5040/ 9781474265027.ch-002

Inglis, D. (2022). On divine wine: Wine gifts between gods and humankind, in P. Howland (ed), Wine and the Gift. London: Routledge.

Inglis, D. and Almila, A.-M. (eds) (2019). The Globalization of Wine. London: Bloomsbury. https://doi.org/10.5040/ 9781474265027 
Inglis, D. and Ho, H. K. (2022) Beyond white: On wine and ethnicity, in S. Charters, M. Demossier, J. Dutton, G. Harding, J. Smith Maguire, D. Marks and T. Unwin (eds), The Routledge Handbook of Wine and Culture (pp. 415423). London: Routledge.

Itçaina X., Roger, A. and Smith, A. (2016). Varietals of Capitalism: A Political Economy of the Changing Wine Industry. Cornell: Cornell University Press. https:/ / doi.org/10.7591/9781501703737

Johansen, D., Friis, K., Skovenborg, E. and Grønbæk, M. (2006). Food buying habits of people who buy wine or beer: Cross sectional study. British Medical Journal, 332(7540), 519-521. https://doi.org/10.1136/ bmj.38694.568981.80

Jones, A. (2003). 'Power in place': Viticultural spatialities of globalization and community empowerment in the Languedoc. Transactions of the Institute of British Geographers, 28(3), 367-382. https://doi.org/10.1111/14755661.00098

Jurca, S. M. (2013). What's in a name?: Geographical indicators, legal protection, and the vulnerability of Zinfandel. Indiana Journal of Global Legal Studies, 20(2), 1445-1471. https:/ / doi.org/10.2979/indjglolegstu.20.2.1445

Kant, I. (1798 [1996]). Anthropology from a Pragmatic Point of View. Carbondale \& Edwardsville: Southern Illinois University Press.

Karpik, L. (2010). Valuing the Unique: The Economics of Singularities. Princeton: Princeton University Press. https:// doi.org/10.1515/9781400835218

Kennedy, T. M. (2017). Boxed wine feminisms: The rhetoric of women's wine drinking in The Good Wife, in M. A. Goldthwaite (ed), Food, Feminisms, Rhetorics (pp. 171-180). Carbondale: Southern Illinois UP.

Kjellgren, B. (2019). Fluid modernity: Wine in China, in D. Inglis and A.-M. Almila (eds), The Globalization of Wine (pp. 115-132). London: Bloomsbury. https:// doi.org/10.5040/9781474265027.ch-007

Koontz, A. and Chapman, N. (2019). About us: Authenticating identity claims in the craft beer industry. Journal of Popular Culture, 52(2), 351-372. https://doi.org/10.1111/jpcu.12787

Kreglinger, G. H. (2019). The Soul of Wine, London: Inter-Varsity Press.

Kruger, S., Rootenberg, C. and Ellis, S. (2013). Examining the influence of the wine festival experience on tourists' quality of life. Social Indicators Research, 111(2), 435-452. https:/ / doi.org/10.1007/s11205-012-0013-0

Kwon, W. and Constantinides, P. (2017). Ideology and moral reasoning: How wine was saved from the $19^{\text {th }}$ century phylloxera epidemic. Organization Studies, 39(8), 1031-1053. https://doi.org/10.1177/0170840617708006

Lachaud-Martin, S., Marache, C., McIntyre, J., Pierre, M. (eds) (2021) Wine, Networks and Scales: Intermediation in the Production, Distribution and Consumption of Wine. New York: Peter Lang. https://doi.org/10.3726/b17374

Lagendijk, A. (2004). Global 'lifeworlds' versus local 'systemworlds': How flying winemakers produce global wines in interconnected locales. Journal of Economic and Social Geography, 95(5), 511-526. https://doi.org/10.1111/ j.0040-747X.2004.00336.x

Lai, M. B., Cavicchi, A., Rickertsen, K., Corsi, A. M. and Casini, L. (2013). Monopoly and wine: The Norwegian case. British Food Journal, 115(2), 1-8. https:// doi.org/10.1108/00070701311302267

Langlois, J., Dacremont, C. and Peyron, D. (2011). Lexicon and types of discourse in wine expertise: The case of vin de garde. Food Quality and Preference, 22, 491-498. https://doi.org/10.1016/j.foodqual.2010.10.008

Latkiewicz. M. (2003). Notes from a wine-tasting, being an inquiry into sensation. Gastronomica, 3(4), 42-45. https://doi.org/10.1525/gfc.2003.3.4.42

Lehrer, A. (1975). Talking about wine. Language, 51(4), 901-923. https://doi.org/10.2307/412700

Lindstrom. M. (1975). California wine categories. Anthropological Linguistics, 17(6), 273-285.

Lissarrague, F. (2016). The Aesthetics of the Greek. Banquet: Images of Wine and Ritual. Princeton: Princeton University Press.

Lorey, T. (2021). The success of rosé wine in France: The millennial revolution. Cornell Hospitality Quarterly, First Published 12 Feb 2021. https://doi.org/10.1177/1938965521993135

Lubasz, H. (1976). Marx's initial problematic: The problem of poverty. Political Studies, 24(1), 24-42. https://doi.org/10.1111/j.1467-9248.1976.tb00091.x

Ludington, C. (2013). The Politics of Wine in Britain. Basingstoke: Palgrave. https://doi.org/10.1057/9780230306226

Lukacs, P. (2002). Inventing Wine. New York: W. W. Norton.

Lukacs, P. (2015). Matters of taste. The American Scholar, 84(3), 44-53.

Lutz, H. F. (1922). Viticulture and Brewing in the Ancient Orient. Leipzig: J. C. Hinrichs'sche. https:// doi.org/10.5962/ bhl.title. 23430

Maher, M. (2001). On vino veritas? Clarifying the use of geographic references on American wine labels. California Law Review, 89(6), 1881-1925. https:// doi.org/10.2307/3481251

Mahy, A. and d'Ath, F. (2017). The case of the 'Champagner sorbet' - unlawful exploitation or legitimate use of the protected name 'Champagne'? European Food and Feed Law Review, 12(1), 43-48.

Maniatis, G. C. (2013) The Byzantine winemaking industry. Byzantion, 83, 229-274. 
Martin, A. L. (2001). Alcohol, Sex, and Gender in Late Medieval and Early Modern Europe. London: Palgrave MacMillan. https://doi.org/10.1057/9781403913937

Matasar, A. B. (2006). Women of Wine: The Rise of Women in the Global Wine Industry. Berkeley: University of California Press. https://doi.org/10.1525/9780520930704

Matthews, M. A. (2016). Terroir and Other Myths of Winegrowing. Berkeley: University of California Press. https://doi.org/10.1525/9780520962002

Mayer-Robin, C. (2008) Alchemies of modern experimentation in writing: Leopardi, Baudelaire, and the distillation of wine symbolism. Romance Notes, 48(2), 185-193. https://doi.org/10.1353/rmc.2008.0018

Mayor, A. (1994). Libation titillation: Wine goblets and women's breasts. Studies in Popular Culture, 16(2), 61-71. https://doi.org/10.1300/J117v02n02_06

McGovern, P. E. (2003). Ancient Wine: The Search for the Origins of Viniculture. Princeton: Princeton University Press.

McGovern, P. E., Jalabadze, M., Batiuk, S., Callahan, M. P., Smith, K. E., Hall, G. R., Kvavadze, E., Maghradze, D., Rusishvili, N., Bouby, L., Failla, O., Cola, G., Mariani, L., Boaretto, E., Bacilieri, R., This, P., Wales, N. and Lordkipanidze, D. (2017). Early neolithic wine of Georgia in the South Caucasus. Proceedings of the National Academy of Sciences of the United States of America, 114(48), E10309-E10318. https://doi.org/10.1073/ pnas. 1714728114

McIntyre, J. (2012). First Vintage: Wine in Colonial New South Wales. Sydney: NewSouth.

Michalski, D. (2013). Real taste: The search for authenticity in wine. Boom: A Journal of California, 3(1), 63-69. https://doi.org/10.1525/boom.2013.3.1.63

Millon, M. (2013). Wine: A Global History. London: Reaktion.

Monterescu, D. and Handel, A. (2019). Liquid indigeneity: Wine, science, and colonial politics in Israel/Palestine. American Ethnologist, 46(3), 313-327. https://doi.org/10.1111/amet.12827

Mora, P. and Moscarola, J. (2010). Representations of the emotions associated with a wine purchasing or consumption experience. International Journal of Consumer Studies, 34, 674-683. https://doi.org/10.1111/j.14706431.2010.00900.x

Moran, W. (1993). The wine appellation as territory in France and California. Annals of the Association of American Geographers, 83(4), 694-717. https://doi.org/10.1111/j.1467-8306.1993.tb01961.x

Morgan, G. and Tresidder, R. (2016). Contemporary Wine Studies: Dancing with Bacchus. London: Routledge. https:// doi.org/10.4324/9781315768274

Navarini, G. (2015). I Mondi del Vino [The Worlds of Wine]. Bologna: Il Mulino.

Nelgen, S., Pinilla, V. and Anderson, K. (eds) (2017). Global Wine Markets, 1860 to 2016: A Statistical Compendium. Adelaide: University of Adelaide Press.

Nelson, M. (2014) Did ancient Greeks drink beer? Phoenix, 68(1/2), 27-46. https://doi.org/10.7834/phoenix.68.12.0027

Nicholas, K. A. (2015). Will we still enjoy pinot noir? Scientific American, 312(1), 60-67. https://doi.org/10.1038/ scientificamerican0115-60

Nicolson, P. (1990) Gender, power and wine selection: A pilot study. Journal of Wine Research, 1(3), 235-242. https://doi.org/10.1080/09571269008717880

Nordlund, S. (2010). Effects of increasing availability of wine and spirits in Norway. Nordic Studies on Alcohol and Drugs, 27(2), 127-140. https://doi.org/10.1177/145507251002700205

Nossiter, J. (2009). Liquid Memory: Why Wine Matters. London: Atlantic.

Nugent, P. (2011). The temperance movement and wine farmers at the cape: Collective action, racial discourse, and legislative reform, C. 1890-1965. The Journal of African History, 52(3), 341-363. https://doi.org/10.1017/ S0021853711000508

Ody-Brasier, A. and Fernandez-Mateo, I. (2017) When being in the minority pays off: Relationships among sellers and price setting in the Champagne industry. American Sociological Review, 82(1), 147-178. https://doi.org/10.1177/0003122416683394

Overton, J. and Banks, G. (2015). Conspicuous production: Wine, capital, and status. Capital \& Class, 39(3), 473491. https://doi.org/10.1177/0309816815607022

Overton, J. and Murray, W. E. (2013). Class in a glass: Capital, neoliberalism and social space in the global wine industry. Antipode, 45, 702-718. https:// doi.org/10.1111/j.1467-8330.2012.01042.x

Overton, J. and Murray, W. E. (2016) Fictive place. Progress in Human Geography, 40(6), 794-809. https://doi.org/10.1177/0309132515625464

Overton, J. and Murray, W. E. (2017). GI blues: Geographical indications and wine in New Zealand, in W. van Caenegem and J. Cleary (eds), The Importance of Place: Geographical Indications as a Tool for Local and Regional Development (pp. 197-220). Springer, Cham. https://doi.org/10.1007/978-3-319-53073-4_8

Pankhurst, R. (2006). The history of grapes, vineyards and wine in Ethiopia, prior to the Italian invasion. Journal of Ethiopian Studies, 39(1/2), 35-54. 
Papakonstantinou, Z. (2009). Wine and wine drinking in the Homeric world. L'Antiquité Classique, 78, 1-24. https://doi.org/10.3406/antiq.2009.3735

Pape, S. (2012). Eine Studie zu Sozialstrukturellen Determinanten und Lebensstilen im Feld des Weines [A Study of Sociostructural Determinants and Lifestyles in the Field of Wine]. Springer: Cham.

Parasecoli, F. (2010). The gender of geographical indications: Women, place, and the marketing of identities. Cultural Studies $\leftrightarrow$ Critical Methodologies, 10(6), 467-478. https://doi.org/10.1177/1532708610372768

Parker, T. (2015). Tasting French Terroir: The History of an Idea. Berkeley: University of California Press. https:// doi.org/10.1525/california/9780520277502.001.0001

Parrott, N., Wilson, N. and Murdoch, J. (2002). Spatializing quality: Regional protection and the alternative geography of food. European Urban and Regional Studies, 9(3), 241-261. https://doi.org/10.1177/ 096977640200900304

Patchell, J. (2008). Collectivity and differentiation: A tale of two wine territories. Environment and Planning A: Economy and Space, 40(10), 2364-2383. https://doi.org/10.1068/a39387

Patterson, T. and Buechsenstein, J. (2018). Wine and Place: A Terroir Reader. Berkeley: University of California Press. https:// doi.org/10.1525/9780520968226

Peace, A. (2006). Barossa slow: The representation and rhetoric of slow food's regional cooking. Gastronomica, 6(1), 51-59. https://doi.org/10.1525/gfc.2006.6.1.51

Peck, G. (2009). The Probibition Hangover: Alcohol in America from Demon Rum to Cult Cabernet. New Brunswick: Rutgers University Press.

Perullo, N. (2021). Epistenology: Wine as Experience. New York: Columbia University Press. https://doi.org/10.7312/ peru19750

Peters, M. A. (2009). Dreams of dionysos: Wine, philosophy and eros. Linguistic and Philosophical Investigations, 8, 3652.

Phillips, C. J. (2016). The taste machine: Sense, subjectivity, and statistics in the California wine world. Social Studies of Science, 46(3), 461-481. https:// doi.org/10.1177/0306312716651504

Phillips, R. (2018). Wine: A Social and Cultural History of the Drink That Changed Our Lives Infinite Ideas. Oxford: Infinite Ideas.

Pincus, R. (2003). Wine, place, and identity in a changing climate. Gastronomica, 3(2), 87-93. https:// doi.org/10.1525/gfc.2003.3.2.87

Pinilla, V. and Ayuda, M.-A. (2002). The political economy of the wine trade: Spanish exports and the international market, 1890-1935. European Review of Economic History, 6(1), 51-85. https://doi.org/10.1017/ S1361491602000035

Pinkert, S. (2017). Weinmilieus: Kleine Soziologie des Weintrinkens [Wine Milieus: A Brief Sociology of Drinking Wine]. Berlin: LIT Verlag.

Pinney, T. (1989). A History of Wine in America. Berkeley: University of California Press.

Pitte, J.-R. (2000). La nouvelle planète des vins/The new planet of wines. Annales de Géographie 109e(614/615), 340344.

Pitte, J.-R. (2013). L'Amour du Vin [Love of Wine]. Paris: CNRS Editions.

Pont, P. C. A. M. and Thomas, H. (2012). The sociotechnical alliance of Argentine quality wine. Science, Technology, Human Values, 37(6), 627-652. https:// doi.org/10.1177/0162243911428623

Purcell, N. (1994). Women and wine in ancient Rome, in M. McDonald (ed), Gender, Drink and Drugs (pp. 191208), Oxford: Berg. https://doi.org/10.4324/9781003135043-10

Rainer, G. (2016). The making of the 'world's highest wine region': Globalization and viticulture restructuring in Salta (NW Argentina). Erdkunde, 70(3), 255-269. https://doi.org/10.3112/erdkunde.2016.03.04

Rainer, G. (2021). Geographies of qualification in the global fine wine market. Environment and Planning A: Economy and Space, 53(1), 95-112. https://doi.org/10.1177/0308518X20934816

Ravenscroft, N. and van Westering, J. (2001). Wine tourism, culture and the everyday: A theoretical note. Tourism and Hospitality Research, 3(2), 149-162. https://doi.org/10.1177/146735840100300206

Rihouet, P. (2013). Veronese's goblets: Glass design and the civilizing process. Journal of Design History, 26(2), 133151. https://doi.org/10.1093/jdh/eps056

Robertson, C. (2009). The sparkling wine war: Pitting trademark rights against geographic indications. Business Law Today, 18(5), 18-22.

Roger, A. (2010). Scholarly constructs and the legitimization of European policies: The circulation of knowledge on wine and the vine. Revue Francaise de Science Politique, 60(2), 1-22. https://doi.org/10.3917/rfspe.602.0001

Rössel, J., Schenk, P. and Eppler, D. (2018). The emergence of authentic products: The transformation of wine journalism in Germany, 1947-2008. Journal of Consumer Culture, 18(3), 453-473. https://doi.org/10.1177/ 1469540516668226 
Rössel, J. and Pape, S. (2014). Who has a wine-identity? Consumption practices between distinction and democratization. Journal of Consumer Culture, 16(2), 614-632. https:// doi.org/10.1177/1469540514536192

Russell, B. F. (2003). Wine, women, and the polis: Gender and the formation of the city-state in archaic Rome. Greece \& Rome, 50(1), 77-84. https:// doi.org/10.1093/gr/50.1.77

Sartre, J.-P. (2001). Colonialism and Neocolonialism. London and New York: Routledge.

Schirmer, R. (2014) Holly[wine] ou le vin dans le cinéma Américain / Holly[wine] or wine in the American cinema. Annales de Géographie, 123e(697), 867-889. https://doi.org/10.3917/ag.697.0867

Sealey, P. R. (2009). New light on the wine trade with Julio-Claudian Britain. Britannia, 40, 1-40. https://doi.org/10.3815/006811309789786061

Shapin, S. (2012). The tastes of wine: Towards a cultural history. Rivista di Estetica, 51(3), 49-94. https://doi.org/10.4000/estetica.1395

Shapin, S. (2016). A taste of science: Making the subjective objective in the California wine world. Social Studies of Science, 46(3), 436-460. https:/ / doi.org/10.1177/0306312716651346

Shepherd, G. M. (2017). Neuroenology: How the Brain Creates the Taste of Wine. New York: Columbia University Press. https://doi.org/10.1212/WNL.0000000000003741

Siegrist, M. and Cousin, M.-E. 2009. Expectations influence sensory experience in a wine tasting. Appetite, 52, 762765. https://doi.org/10.1016/j.appet.2009.02.002

Silverstein, M. (2016). Semiotic vinification and the scaling of taste, in E. Summerson Carr and M. Lempert (eds), Scale: Discourse and Dimensions of Social Life (pp. 185-212). Berkeley: University of California Press.

Simons, T. and Roberts, P. W. (2008). Local and non-local prefounding experience and new organizational form penetration: The case of the Israeli wine industry. Administrative Science Quarterly, 53(2), 235-265. https://doi.org/10.2189/asqu.53.2.235

Simpson, J. (2011). Creating Wine: The Emergence of a World Industry, 1840-1914. Princeton: Princeton University Press. https:// doi.org/10.23943/princeton/9780691136035.003.0007

Skinner, W. (2016) Trust your senses: Growing wine and making place in McLaren Vale, in S. R. Hemer and A. Dundon (eds), Emotions, Senses, Spaces: Ethnographic Engagements and Intersections (pp. 175-191). Adelaide: University of Adelaide Press. https://doi.org/10.20851/emotions-11

Smith Maguire, J. (2013). Provenance as a filtering and framing device in the qualification of wine. Consumption, Markets and Culture, 16(4), 368-391. https://doi.org/10.1080/10253866.2012.662829

Smith Maguire, J. (2018a). Taste as market practice: The example of 'natural' wine, in A. Venkatesh, S. Cross, C. Ruvalcaba and R. Belk (eds), Consumer Culture Theory Research in Consumer Behavior, Vol. 19 (pp. 71-92). Bingley: Emerald. https://doi.org/10.1108/S0885-211120180000019005

Smith Maguire, J. (2018b). The taste for the particular: A logic of discernment in an age of omnivorousness. Journal of Consumer Culture, 18(1), 3-20. https:// doi.org/10.1177/1469540516634416

Smith Maguire, J. (2018c). Wine, the authenticity taste regime and rendering craft, in E. Bell, G., Mangia, S. Taylor and M. L. Toraldo (eds), The Organization of Craft Work: Identities, Meanings and Materialities (pp. 60-78). London: Routledge. https://doi.org/10.4324/9781315205861-4

Smith Maguire, J. (2019a). Media representations of the nouveaux riches and the cultural constitution of the global middle class. Cultural Politics, 15(1), 29-47. https://doi.org/10.1215/17432197-7289472

Smith Maguire, J. (2019b). Natural wine and the globalization of a taste for provenance, in D. Inglis and A.-M. Almila (eds), The Globalization of Wine (pp. 171-189). London: Bloomsbury. https://doi.org/10.5040/ 9781474265027.ch-010

Smith Maguire, J. and Charters, S. (2021). Aesthetic logics, terroir and the lamination of grower Champagne. Consumption, Markets and Culture, 24(1), 75-96. https://doi.org/10.1080/10253866.2020.1730823

Smith Maguire, J. and Lim, M. (2015). Lafite in China: Media representations of 'wine culture' in new markets. Journal of Macromarketing, 35(2), 229-242. https://doi.org/10.1177/0276146714529975

Smith, A. (2016). Terror and Terroir: The Winegrowers of the Languedoc and Modern France. Manchester: Manchester University Press. https:// doi.org/10.7765/9781526101112

Smith, B. C. (ed) (2007). Questions of Taste: The Philosophy of Wine. Oxford: Oxford University Press.

Smith, D. E., Mitry, D. J., Jenster, P. V. and Jenster, L. V. (2013). International Business of Wine. Chengdu: Nordic International Management Institute Press.

Solomon, G. E. A. (1990). Psychology of novice and expert wine talk. The American Journal of Psychology, 103(4), 495517. https://doi.org/10.2307/1423321

Sommers, B. J. (2008) The Geography of Wine: How Landscapes, Cultures, Terroir, and the Weather Make a Good Drop. New York: Plume.

Stanislawski, D. (1975). Dionysus westward: Early religion and the economic geography of wine. Geographical Review, 65(4), pp.427-444. https://doi.org/10.2307/213743 
Stephens, M. and Neil, R. (2010). 'You do know it's only got one bathroom': Biography, wine and small stories. Memory Studies, 4(2), 221-233. https:// doi.org/10.1177/1750698010376318

Sternsdorff Cisterna, N. (2014). Unexpected moments and the wine experience. Food and Foodways, 22, 90-111. https://doi.org/10.1080/07409710.2014.892734

Storchmann, K. (2012). Wine economics. Journal of Wine Economics, 7(1), 1-33. https://doi.org/10.1017/jwe.2018.9

Taplin, I. M. (2011). The Modern American Wine Industry: Market Formation and Growth in North Carolina. London: Pickering and Chatto.

Teil, G. (2012). No such thing as terroir? Objectivities and the regimes of existence of objects. Science, Tecbnology \& Human Values, 37(5), 478-505. https://doi.org/10.1177/0162243911423843

Teil, G. (2021). Amateurs' exploration of wine - A pragmatic study of taste. Theory Culture \& Society, 38(5), 137157. https://doi.org/10.1177/02632764211029347

Teil, G. and Hennion, A. (2004). Discovering quality or performing taste? A sociology of the amateur, in M. Harvey, A. McMeekin and A. Warde (eds), Qualities of Food (pp. 19-37). Manchester: Manchester University Press.

Teil, G., Barrey, S., Floux, P. and Hennion, A. (2011). Le Vin et l'Environnement: Faire Compter la Différence [Wine and the Environment: Making the Difference Count]. Paris: Presses de l'Ecole des Mines. https://doi.org/10.4000/ books.pressesmines.514

Thorpe, C. and Inglis, D. (2019). Do 'global generations' exist? from Mannheim to Beck and beyond. Youth and Globalization, 1(1), 40-64. https://doi.org/10.1163/25895745-00101003

Tiefenbacher, J. P. and Townsend, C. (2019). The semiofoodscape of wine, in S. Brunn and R. Kehrein (eds), Handbook of the Changing World Language Map. Cham: Springer. https://doi.org/10.1007/978-3-319-734002_213-2

Törrönen, J. and Maunu, A. (2017). Whilst it's red wine with beef, it's booze with a cruise! Nordic Studies on Alcohol and Drugs, 24(2), 177-199. https:/ / doi.org/10.1177/145507250702400212

Trubek, A. (2006). Wine is dead! Long live wine! Gastronomica, 6(2), 88-90. https:/ / doi.org/10.1525/gfc.2006.6.2.88

Trubek, A. (2008). The Taste of Place: A Cultural Journey into Terroir. Berkeley: University of California Press.

Turner, S. (2010). Networks of learning within the English wine industry. Journal of Economic Geography, 10(5), 685715. https:// doi.org/10.1093/jeg/lbp053

Ugaglia, A. A. and Cardebat, J.-M. (eds) (2019). The Palgrave Handbook of Wine Industry Economics. London: Palgrave

Ulin, R. C. (1987). Writing and power: The recovery of winegrowing histories in the southwest of France. Anthropological Quarterly, 60(2), 77-82. https://doi.org/10.2307/3317998

Ulin, R. C. (1995). Invention and representation as cultural capital: Southwest French winegrowing history. American Anthropologist, 97(3), 519-527. https://doi.org/10.1525/aa.1995.97.3.02a00100

Ulin, R. C. (2002). Work as cultural production: Labour and self-identity among southwest French wine-growers. Journal of the Royal Anthropological Institute, 8(4), 691-712. https:/ / doi.org/10.1111/1467-9655.00129

Ulin, R. C. (2004). Globalization and alternative localities. Anthropologica, 46(2), 153-164. https://doi.org/10.2307/ 25606191

Ulin, R. C. (2013). Terroir and locality: An anthropological perspective, in R. E. Black and R. C. Ulin (eds), Wine and Culture: Vineyard to Glass (pp. 67-84). London: Bloomsbury. https://doi.org/10.5040/9781350042254.ch004

Unwin, T. (1991). Wine and the Vine: An Historical Geography of Viticulture and the Wine Trade. London: Routledge.

Unwin, T. (2017). Geography of wine. Oxford Bibliographies. Available at: https:/ /www.oxfordbibliographies.com/ view/document/obo-9780199874002/obo-9780199874002-0166.xml (Accessed 6 December 2021).

Vannini, P., Ahluwalia-Lopez, G., Waskul, D. and Gottschalk, S. (2010). Performing taste at wine festivals: A somatic layered account of material culture. Qualitative Inquiry, 16(5), 378-396. https://doi.org/10.1177/ 1077800410366939

Varriano, J. (2010). Wine: A Cultural History. London: Reaktion.

Veseth, M. (2012). Wine Wars. Lanham: Rowman and Littlefield.

Voronov, M., De Clercq, D. and Hinings, C. R. (2013). Institutional complexity and logic engagement: An investigation of Ontario fine wine. Human Relations, 66(12), 1563-1596. https://doi.org/10.1177/ 0018726713481634

Waters, S. (2010). Globalization, the Confédération Paysanne, and symbolic power. French Politics, Culture \& Society, 28(2), 96-117. https://doi.org/10.3167/fpcs.2010.280208

Whalen, P. (2009). Insofar as the ruby wine seduces them: Cultural strategies for selling wine in inter-War Burgundy. Contemporary European History, 18(1), 67-98. https://doi.org/10.1017/S0960777308004839

White, O. (2017). Roll out the barrel: French and Algerian ports and the birth of the wine tanker. French Politics, Culture \& Society, 35(2), 111-132. https:// doi.org/10.3167/fpcs.2017.350209

Wilson, H. (2012). Wine and Words in Classical Antiquity and the Middle Ages. London: Bristol Classical Press. 
Woodward I. and Ellison D. (2012). How to make an iconic commodity: The case of Penfolds' Grange Wine, in J. C. Alexander, D. Bartmanski and B. Giesen (eds), Iconic Power. Cultural Sociology (pp. 155-169). New York: Palgrave Macmillan. https://doi.org/10.1057/9781137012869_10

Yang, Y. and Paladino, A. (2015). The case of wine: Understanding Chinese gift-giving behavior. Marketing Letters, 26(3), 335-361. https:/ / doi.org/10.1007/s11002-015-9355-0

Younger, Y. A. (1966). Gods, Men and Wine. London: Wine and Food Society.

Zhang, J. (2018). Rituals, discourses, and realities: Serious wine and tea tasting in contemporary China. Journal of Consumer Culture, 20(4), 637-655. https:/ / doi.org/10.1177/1469540518773812

Zhao, W. (2005). Understanding classifications: Empirical evidence from the American and French wine industries. Poetics, 33, 179-200. https://doi.org/10.1016/j.poetic.2005.09.010

Zhao, W. (2008). Social categories, classification systems, and determinants of wine price in the California and French wine industries. Sociological Perspectives, 51(1), 163-199. https://doi.org/10.1525/sop.2008.51.1.163

Zhao, W. and Zhou, Z. (2011). Status inconsistency and product valuation in the California wine market. Organization Science, 22(6), 1435-1448. https://doi.org/10.1287/orsc.1100.0597

Zheng, X. (2019). Narrating terroir. Food, Culture, Society, 22(3), 280-298. https://doi.org/10.1080/ 15528014.2019.1596435

Zolberg, V. (1990). Constructing A Sociology of the Arts. New York: Cambridge University Press. https://doi.org/10.1017/CBO9780511557712 